
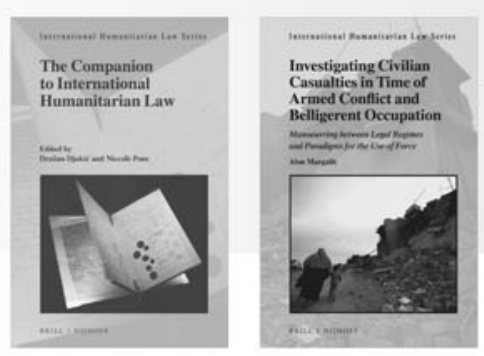

\section{The Companion to International Humanitarian Law}

Edited by Dražan Djukić, Pre-Trial Division of the International Criminal Court and Niccolò Pons, Kosovo Specialist Chambers

The Companion to International Humanitarian Law offers a much-needed tool for both scholars and practitioners, supplying information accessible enough to enable a variety of users to quickly familiarise themselves with it and sufficiently comprehensive to be a source for reflection and further research for more demanding users. Its aim is to facilitate the practical application of IHL, and be of use to a wide audience interested in or confronted with IHL, ranging from professionals in humanitarian assistance and protection in the field, legal officers and advisers at the national and international level, trainers, academics, scholars, and students.

August 2018

Hardback (approx. 780 pp.)

ISBN 9789004342002

Price 6275 / US\$ 331

E-ISBN 9789004342019

E-Price 6249 / US\$ 299

International Humanitarian Law Series, 55

\section{Investigating Civilian}

Casualties in Time of Armed

Conflict and Belligerent

\section{Occupation}

Manoeuvring between Legal Regimes and Paradigms for the Use of Force

\section{Dr. Alon Margalit}

In Investigating Civilian Casualties Alon Margalit discusses the appropriate response to State-caused fatalities. Highlighting various legal and practical challenges, the State's duty to investigate is considered amid increasing public scrutiny and influence of human rights law during military operations.

July 2018

Hardback (approx. 260 pp.)

ISBN 9789004368200

Price $€ 135$ / US\$ 155

E-ISBN 9789004368217

E-Price 6123 / US\$ 141

International Humanitarian Law Series, 54
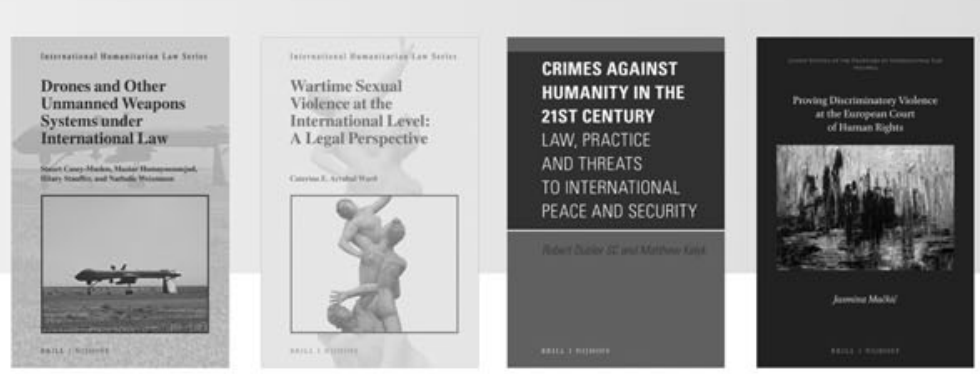

Drones and Other Unmanned Weapons Systems under International Law

Stuart Casey-Maslen, University of Pretoria, Maziar Homayounnejad, University of Warwick, Hilary Stauffer, United Nations, and Nathalie Weizmann, United Nations

Drone strikes have become a key feature of counterterrorism operations in an increasing number of countries. This work explores the various domestic and international legal regimes that govern the manufacture, transfer, and use of armed drones as well as fully autonomous weapons systems where computer algorithms decide who or what to target and when to fire.

August 2018

Hardback (vi, 255 pp.)

ISBN 9789004363250

Price 6155 / US\$ 179

E-ISBN 9789004363267

E-Price 6140 / US\$ 161

International Humanitarian Law Series, 53

\section{Wartime Sexual Violence} at the International Level:

\section{A Legal Perspective}

\section{Dr. Caterina E. Arrabal Ward}

In Wartime Sexual Violence at the International Level: A Legal Perspective, Dr. Caterina E. Arrabal Ward argues that the human rights of victims of sexual violence are not presently entirely contemplated or protected.

\section{July 2018}

Hardback (x, 260 pp.)

ISBN 9789004360075

Price $€ 135$ / US\$ 162

E-ISBN 9789004360082

E-Price $€ 122$ / US\$ 146

International Humanitarian Law Series, 52

\section{Crimes against Humanity in the 21st Century \\ Law, Practice and Threats to \\ International Peace and Security}

Dr Robert Dubler SC and Matthew Kalyk With a foreword by Geoffrey Robertson QC

In Crimes Against Humanity in the 21st Century, Dr Robert Dubler SC and Matthew Kalyk provide a comprehensive analysis of crimes against humanity in international criminal law, including an analysis of its history, its present definition and its raison dêtre.

July 2018

Hardback (approx. 1,050 pp.

ISBN 9789004347670

Price $€ 275$ / US\$ 331

E-ISBN 9789004347687

E-Price $€ 249$ / US\$ 299

\section{Proving Discriminatory} Violence at the European Court of Human Rights

Dr. Jasmina Mačkić

In Proving Discriminatory Violence at the European Court of Human Rights Jasmina Mačkić explores the engagement of a fundamental European institution with the phenomenon of discriminatory violence, namely, the European Court of Human Rights.

July 2018

Hardback (viii, 317 pp.)

ISBN 9789004359840

Price $€ 155$ / US\$ 186

E-ISBN 9789004359857

E-Price $€ 141$ / US\$ 169

Leiden Studies on the Frontiers of International Law, 4
To stay informed about Brill Nijhoff's program, subscribe to our Newsletter(s) at brill.com/email-newsletters, or follow us on Facebook or Twitter

f Facebook.com/BrillNijhof y Twitter.com/Brill_Law

\section{BRILL | NIJHOFF}



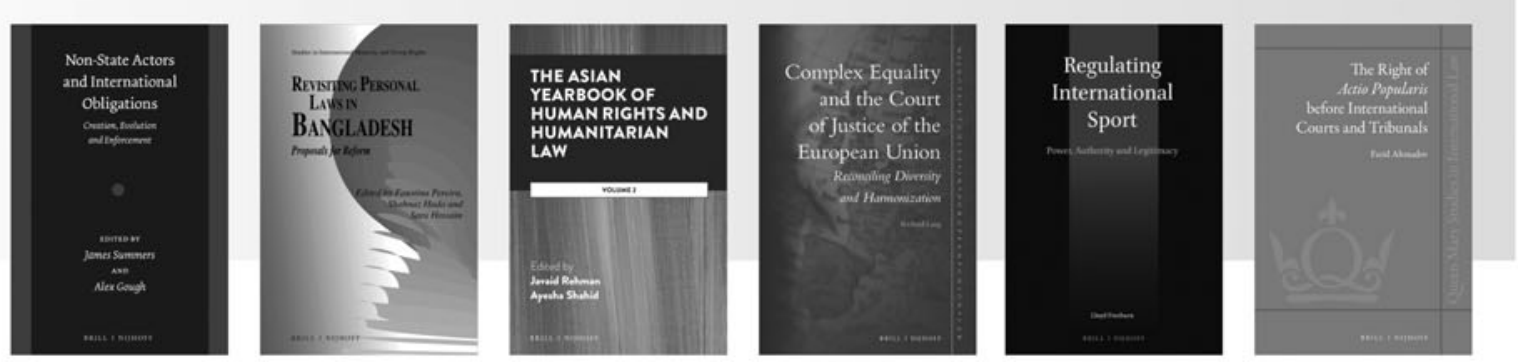

\section{Non-State Actors and International Obligations}

Creation, Evolution and Enforcement

Edited by Dr James Summers, University of Lancaster and Alex Gough, University of Lancaster

This collection studies the contribution of nonstate actors to international obligations. Chapters by academics and practitioners address the role that these actors play in the sources of obligations, their implementation, human rights aspects, dispute settlement, responsibility and legal accountability.

July 2018

Hardback (xxxvi, 486 pp.)

ISBN 9789004340237

Price $€ 185$ / US\$ 222

E-ISBN 9789004340251

E-Price $€ 167$ / US\$ 200

\section{Revisiting Personal Laws in Bangladesh \\ Proposals for Reform}

Edited by Faustina Pereira, Shahnaz Huda and Sara Hossain

This unique volume gives a voice to the different religious communities affected by the current laws and practices in force in Bangladesh. The reader will find an overview and gain understanding of the legal issues that need to be addressed in each case.

August 2018

Hardback (approx. 270 pp.)

ISBN 9789004357341

Price $€ 176$ / US\$ 212

E-ISBN 9789004357273

E-Price $€ 160$ / US\$ 192

Studies in International Minority and Group Rights, 14
The Asian Yearbook of Human Rights and Humanitarian Law

Volume 2, 2018

Edited by Javaid Rehman and Ayesha Shahid

The Asian Yearbook of Human Rights and Humanitarian Law aims to publish peer-reviewed scholarly articles and reviews as well as significant developments in human rights and humanitarian law. It examines international human rights and humanitarian law with a global reach, though its particular focus is on the Asian region. The focused theme of Volume II is: Islamic Law and its Implementation in Asia and the Middle East.

August 2018

Hardback (approx. 490 pp.)

ISBN 9789004346871

Price $€ 325$ / US\$ 374

E-ISBN 9789004346888

E-Price $€ 295$ / US\$ 340

The Asian Yearbook of Human Rights and Humanitarian Law, 2

Complex Equality and the Court of Justice of the European Union

Reconciling Diversity and

Harmonization

Richard Lang, University of Brighton

In Complex equality and the Court of Justice of the European Union: Reconciling Diversity and Harmonization, Richard Lang proposes that the EU's judges adopt Walzerian Complex Equality as a complement to their existing, and unsatisfactory, test for equality based on Aristotle.

July 2018

Hardback (approx. 440 pp.)

ISBN 9789004299993

Price $€ 169$ / US\$ 195

E-ISBN 9789004354265

E-Price $€ 154$ / US\$ 177

Nijhoff Studies in European Union Law, 14

\section{Regulating International Sport}

Power, Authority and Legitimacy

Lloyd Freeburn, University of Melbourne

In Regulating International Sport: Power, Authority and Legitimacy Lloyd Freeburn provides a groundbreaking account of the legal basis of regulatory power in international sport and outlines the reforms necessary to give the regime legality and legitimacy.

September 2018

Hardback

ISBN 9789004379787

E-ISBN 9789004379794

E-Price $€ 115$ / US\$ 138

\section{The Right of Actio Popularis} before International Courts and Tribunals

Farid Ahmadov, "ADA" University

In The Right of Actio Popularis before International Courts and Tribunals Farid Ahmadov provides a detailed analysis of the elements of actio popularis and its operation before various international courts and tribunals.

September 2018

Hardback

ISBN 9789004366978

Price $€ 198$ / US\$ 238

E-ISBN 9789004380981

E-Price $€ 180$ / US\$ 216

Queen Mary Studies in International Law, 31

Discount code 7o65o entitles ASIL members to $20 \%$ discount on Brill | Nijhoff print books, with the exception of Hague Academy titles. No additional discounts apply. Order directly via brill.com or our distributors: brillna@turpin-distribution.com / brill@turpin-distribution.com.

BRILL | NIJHOFF
Price $€ 127$ / US\$ 153 

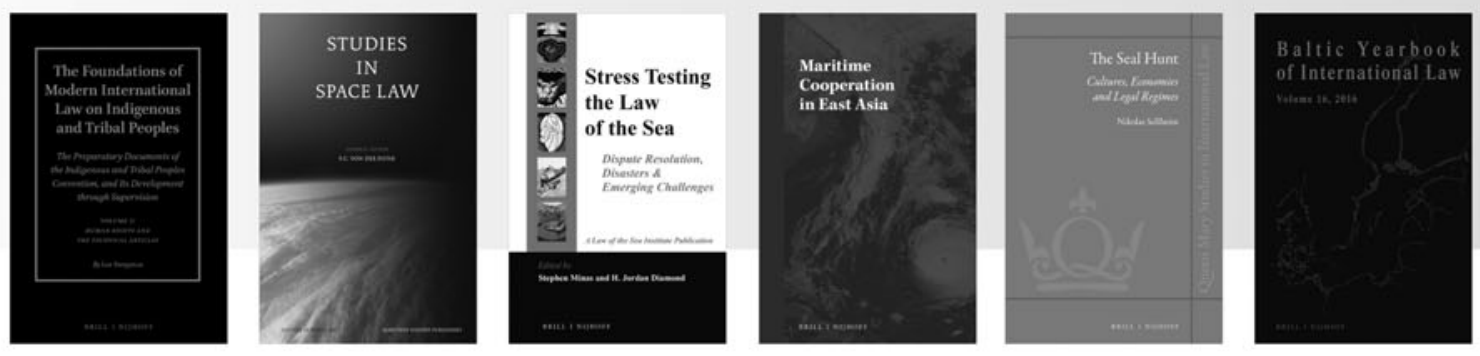

\section{The Foundations of Modern} International Law on Indigenous and Tribal Peoples

The Preparatory Documents of the Indigenous and Tribal Peoples Convention, and Its Development through Supervision.

Volume 2: Human Rights and the Technical Articles

\section{Lee Swepston}

The adoption in 2007 of the UN Declaration on the Rights of Indigenous Peoples (UNDRIP), and the ongoing discussions in the international human rights community about the relative merits, impact and legal validity of the UN and ILO instruments, make it all the more important to understand how Convention 169 was adopted.

August 2018

Hardback (approx. 260 pp.)

ISBN 9789004289079

Price $€ 166$ / US\$ 199

E-ISBN 9789004289086

E-Price $€ 151$ / US\$ 181

The Travaux Préparatoires of Multilateral Treaties, 4

\section{How High the Sky?}

The Definition and Delimitation of Outer Space and Territorial Airspace in International Law

\section{Dr Thomas Gangale}

In How High the Sky?, Thomas Gangale explores the oldest and most intractable controversy in space law: how far up does national airspace go, and where does the international environment of outer space begin?

September 2018

Hardback (approx. 575 pp.)

ISBN 9789004366015

Price $€ 182$ / US\$ 219

E-ISBN 9789004366022

E-Price $€ 165$ / US\$ 198

Studies in Space Law, 13

\section{Stress Testing the Law of} the Sea

Dispute Resolution, Disasters \& Emerging Challenges

Edited by Stephen Minas, Transnational Law Institute, King's College London and H. Jordan Diamond, Center for Law, Energy, and the Environment

In Stress Testing the Law of the Sea: Dispute Resolution, Disasters \& Emerging Challenges, leading UNCLOS practitioners and scholars examine key developments in dispute resolution and the impacts on ocean law of climate change, disasters and expanding energy exploration.

September 2018

Hardback

ISBN 9789004352919

Price $€ 160$ / US\$ 192

E-ISBN 9789004352926

E-Price $€ 145$ / US\$ 174

\section{Global Commons and the Law of the Sea}

Edited by Keuyan Zou, University of Central Lancashire

Global Commons and the Law of the Sea respectively addresses the principle of the common heritage of mankind ( $\mathrm{CHM})$, freedoms of high seas, deep sea mining and international seabed, area beyond national jurisdiction ( $\mathrm{ABNJ}$ ) governance, management of geoengineering and generic resources, and recent developments in the polar regions.

\section{August 2018}

Hardback

ISBN 9789004373327

Price $€ 105$ / US\$ 121

E-ISBN 9789004373334

E-Price $€ 95$ / US\$ 110

Maritime Cooperation in East Asia, 5

\section{The Seal Hunt}

Cultures, Economies and Legal Regimes

\section{Nikolas Sellheim}

In The Seal Hunt: Cultures, Economies and Legal Regimes, Sellheim offers an analysis of the cultural, economic and legal aspects circling around the global seal hunt, with a focus on the European Union and the World Trade Organization.

\section{September 2018}

Hardback

ISBN 9789004324985

Price $€ 195$ / US\$ 235

E-ISBN 9789004378612

E-Price $€ 174$ / US\$ 209

Queen Mary Studies in International Law, 30

\section{Baltic Yearbook of International Law, Volume 16 (2016)}

Edited by Lauri Mälksoo, Ineta Ziemele and Dainius Žalimas

This volume of the Baltic Yearbook of International Law contains articles based on presentations delivered at the Annual Conference of the European Society of International Law which took place in Rĩga, Latvia, from 8-10 September 2016.

\section{July 2018}

ISBN 9789004359772

Price $€ 363$ / US\$ 418

Baltic Yearbook of International Law, 16
To stay informed about Brill Nijhoff's program, subscribe to our Newsletter(s) at brill.com/email-newsletters, or follow us on Facebook or Twitter

f Facebook.com/BrillNijhoff
Y Twitter.com/Brill_Law 

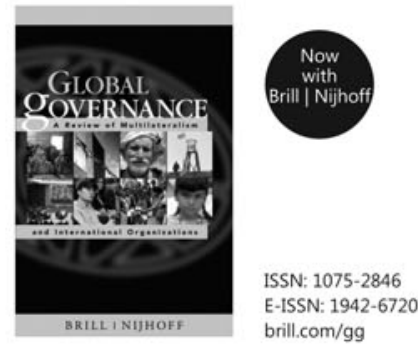

\section{Global Governance:}

\section{A Review of Multilateralism and International Organizations}

Editors: Kendall Stiles, Brigham Young University and Alynna Lyon, University of New Hampshire

Global Governance showcases the expertise of leading scholars and practitioners concerned with the processes of international cooperation and multilateralism. The result is a provocative exploration of the most pressing transnational challenges of our time-issues of peace and security, development, human rights, the environment, and health among thempresenting groundbreaking research, opinion pieces, and book reviews.

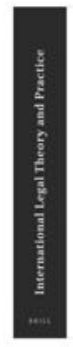

BRP
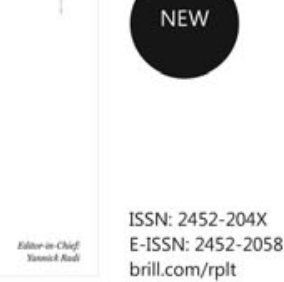

\section{Brill Research Perspectives in International Legal Theory and Practice}

Editor-in-Chief: Prof. Dr. Yannick Radi, University of Louvain

This journal allows us to understand the dynamics that are at play in international law and to reclaim its history whilst, most importantly, encouraging international lawyers to reimagine and rethink its possibilities.
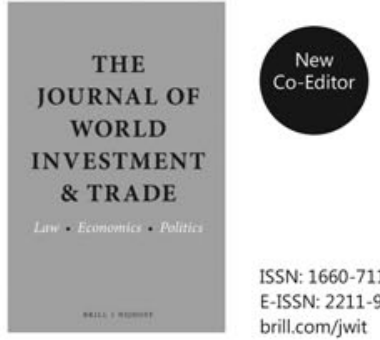

ISSN: $1660-7112$

E-ISSN: 2211-9000

brill.com/jwit

\section{The Journal of World Investment \& Trade}

Law $\cdot$ Economics $\cdot$ Politics

Editors-in-Chief: Stephan W. Schill, University of Amsterdam and Hélène Ruiz Fabri, MPI, Luxembourg

A double-blind peer-reviewed journal that focuses on the legal aspects of foreign investment relations in a broad sense.

Now included in Scopus.
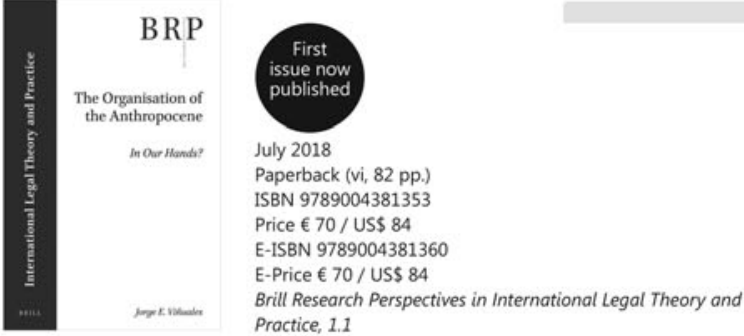

The Organisation of the Anthropocene In Our Hands?

Jorge E. Viñuales, The University of Cambridge

In The Organisation of the Anthropocene, J. E. Vinuales explores the legal dimensions of the currently advocated new geological epoch called the Anthropocene, in which humans are the defining force.
Discount code 70650 entitles ASIL members to $20 \%$ discount on Brill | Nijhoff print books, with the exception of Hague Academy titles. No additional discounts apply. Order directly via brill.com or our distributors:

brillna@turpin-distribution.com / brill@turpin-distribution.com.
To stay informed about Brill Nijhoff's program, subscribe to our Newsletter(s) at brill.com/email-newsletters, or follow us on Facebook or Twitter

ff Facebook.com/BrillNijhoff Twitter.com/Brill_Law 


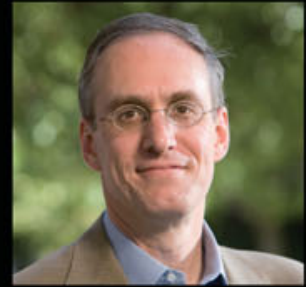

Curtis Bradley

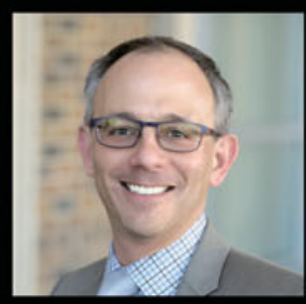

Laurence Helfer

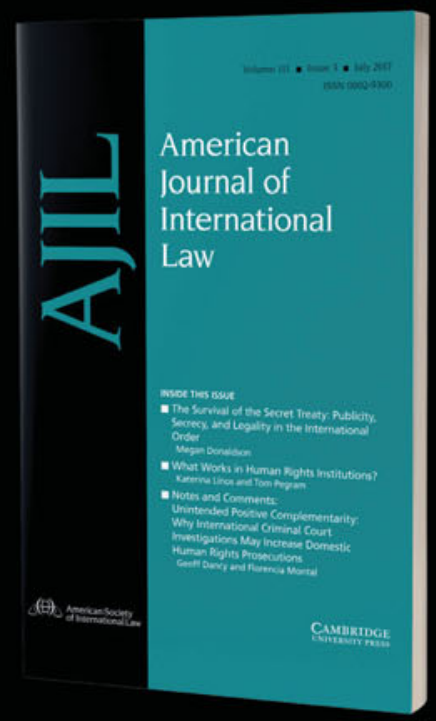

Find out more about submitting a manuscript at cambridge.org/ AJILSubmissions

\section{Interested in submitting an article to the American Journal of International Law?}

The new Editors-in-Chief of the American Journal of International Law (AJIL), Curtis Bradley and Laurence Helfer, encourage scholars to submit article manuscripts, essays and other work.

\section{Advantages of publishing in AJIL}

\section{Q Double-blind peer review of eligible manuscripts by the Board of Editors.}

Commited to fast and thorough review, with

$\cdots$ feedback provided by the Editors-in-Chief on many manuscripts.

Extensive international readership, including

(2) over 8,000 institutions and 4,000 ASIL members.

$\Delta \Delta$ Publication in a journal that has featured work by leading international law scholars since 1907. 


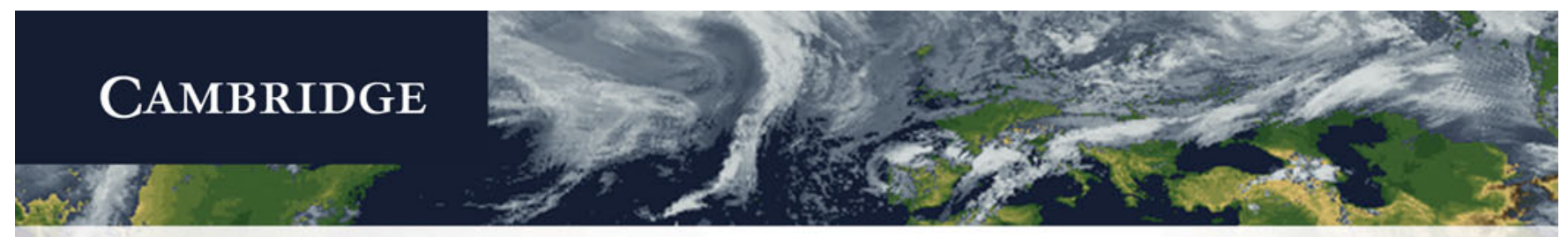

\section{ASIL STUDIES IN INTERNATIONAL LEGAL THEORY}

The purpose of the ASIL Studies in International Legal Theory is to clarify and improve the theoretical foundations of international law. Too often the progressive development and implementation of international law has foundered on confusion about first principles. This series raises the level of public and scholarly discussion about the structure and purposes of the world legal order and how best to achieve global justice through law. This series grows out of the International Legal Theory project of the American Society of International Law. The ASIL Studies in International Legal Theory deepen this conversation by publishing scholarly monographs and edited volumes of essays considering subjects in international legal theory.

\section{RECENT TITLES IN THIS SERIES}

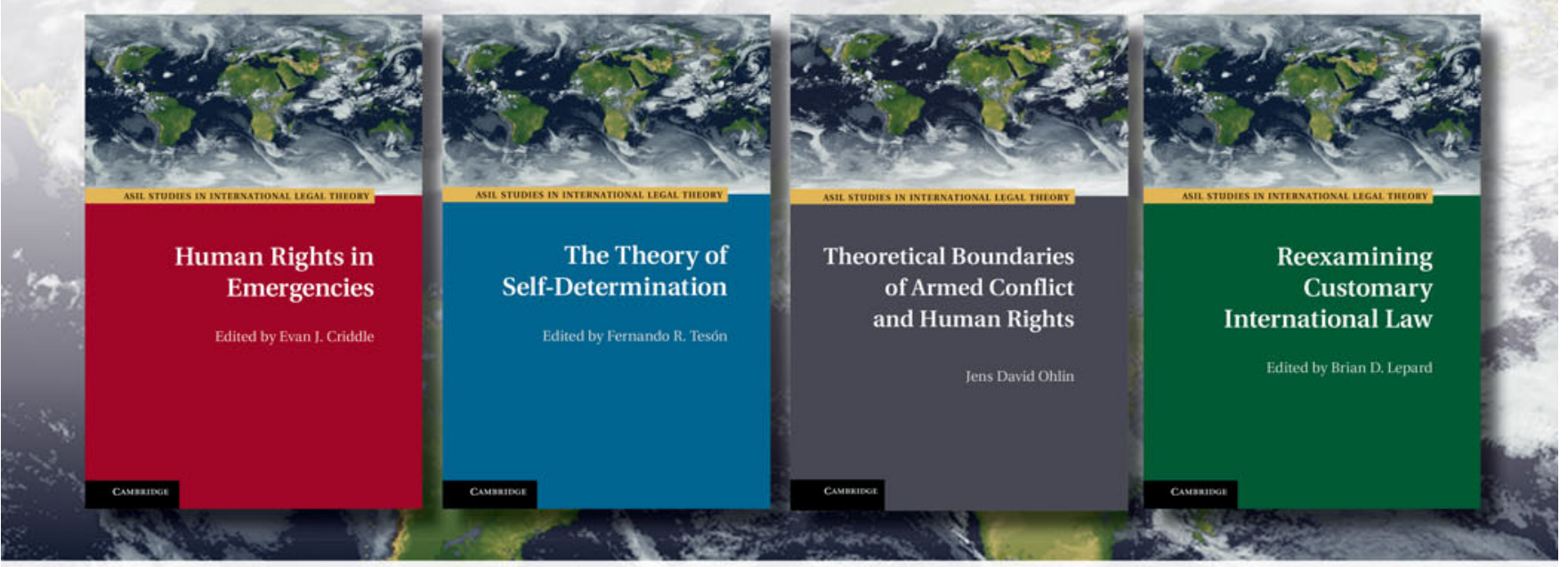

For more information, visit

CAMBRIDGE cambridge.org/ASIL 


\section{Cambridge University Press Home of the best journals content in \\ International Law}
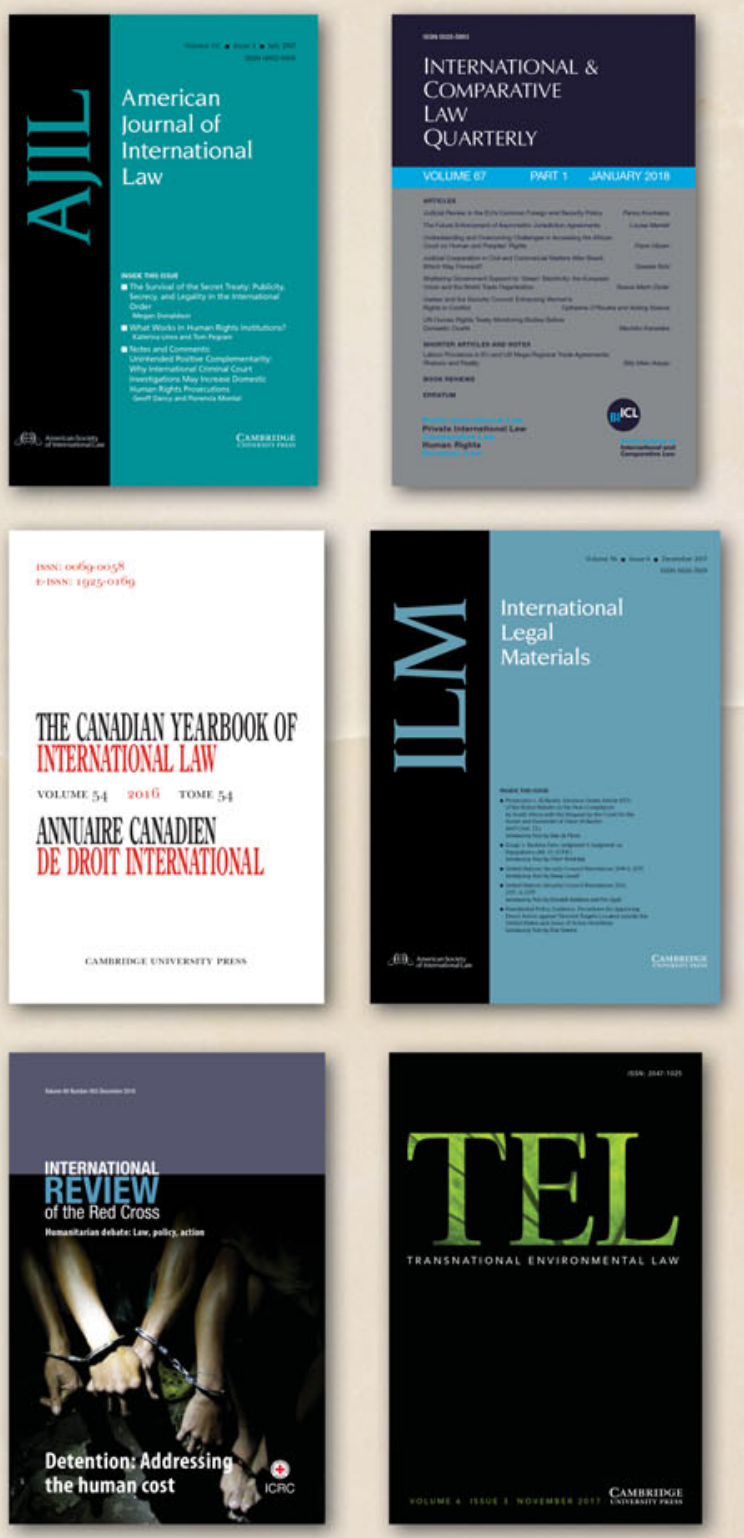
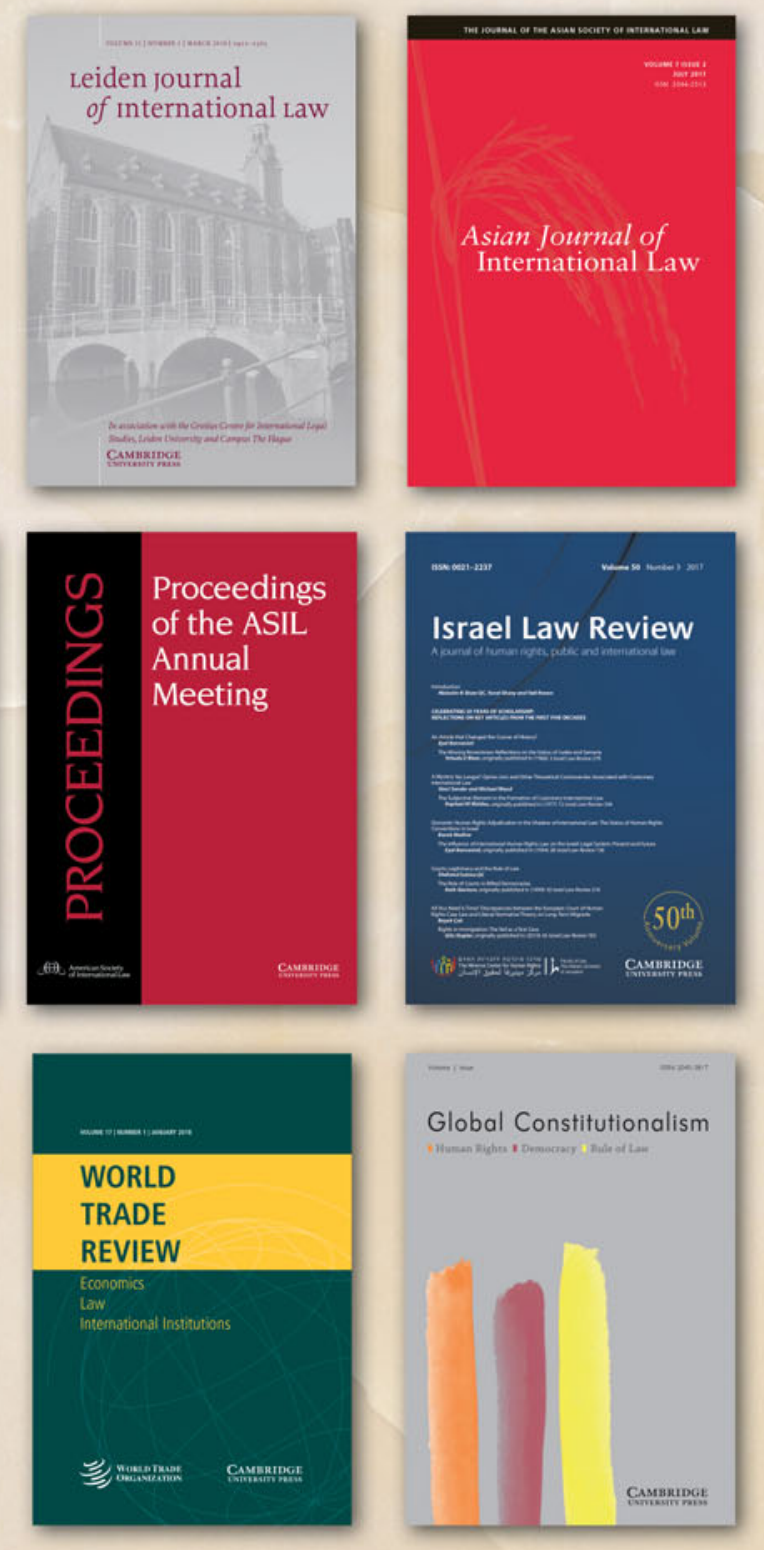

Explore leading law journals covering a wide range of international legal perspectives 


\section{CAMBRIDGE}

\section{CAMBRIDGE IS INTERNATIONAL LAW}
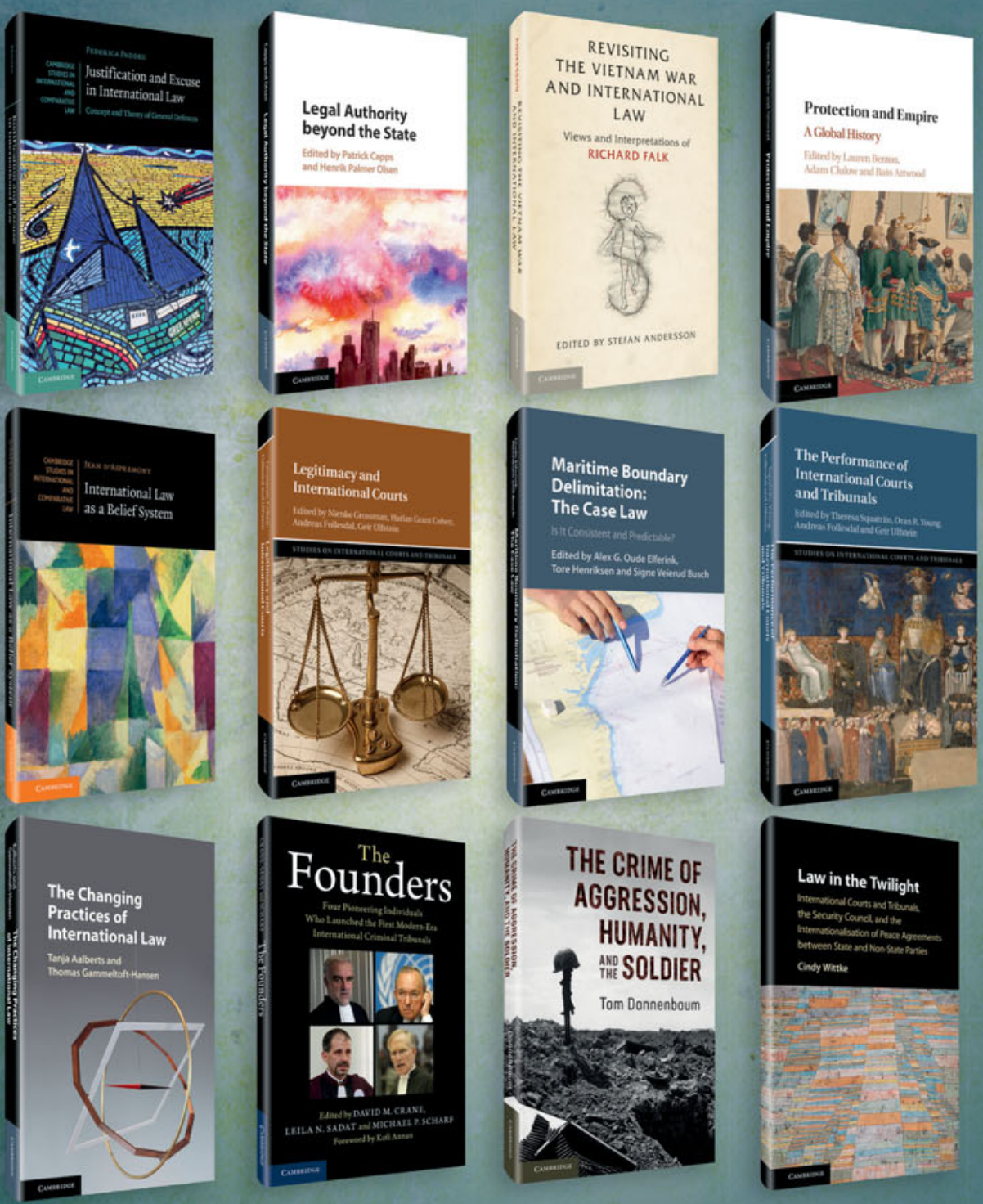

cambridge.org/law 


\section{New International Law Titles from Hart Publishing}

For more information and to order visit www.isbs.com

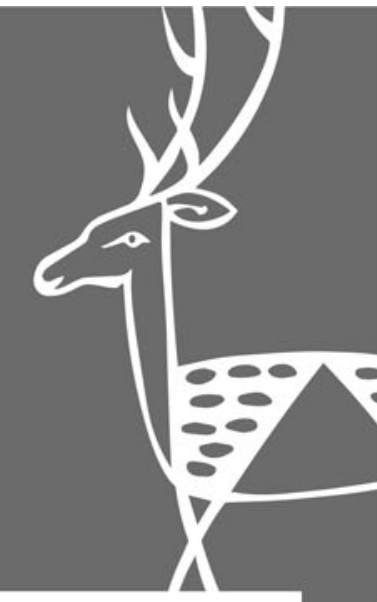

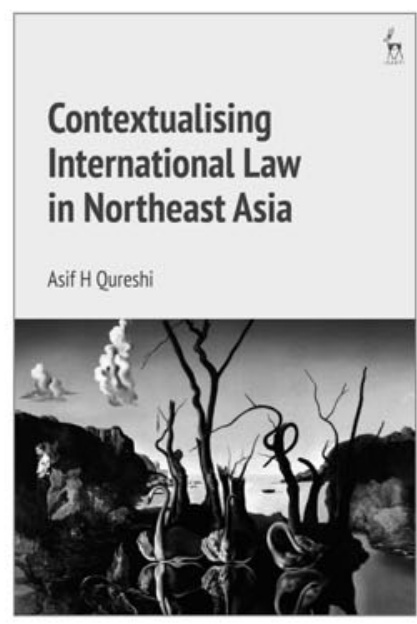

September 2018

US $\$ 68$

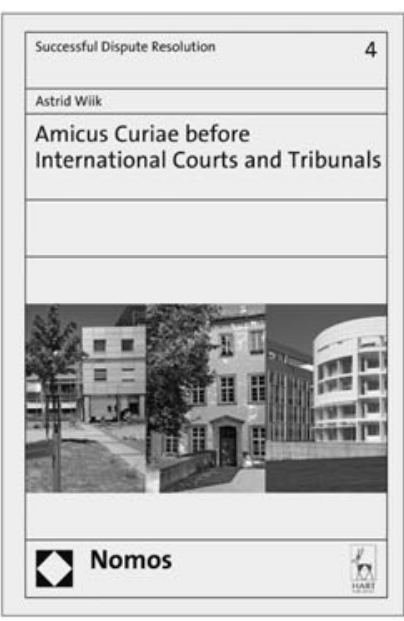

May 2018

US $\$ 304$

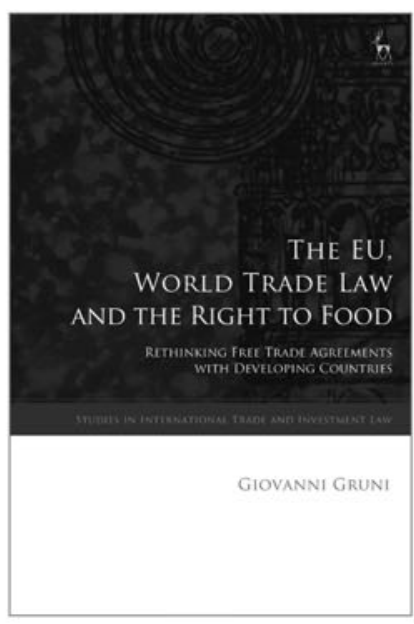

August 2018

US $\$ 88$

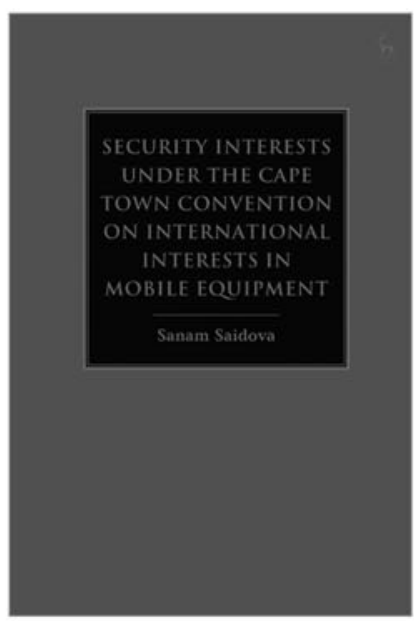

June 2018

US $\$ 94$

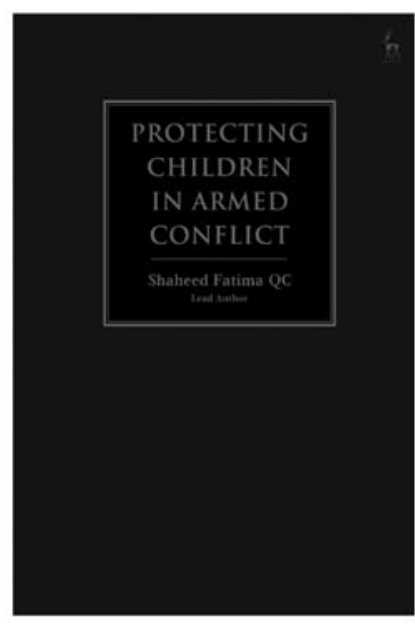

September 2018 US $\$ 148$

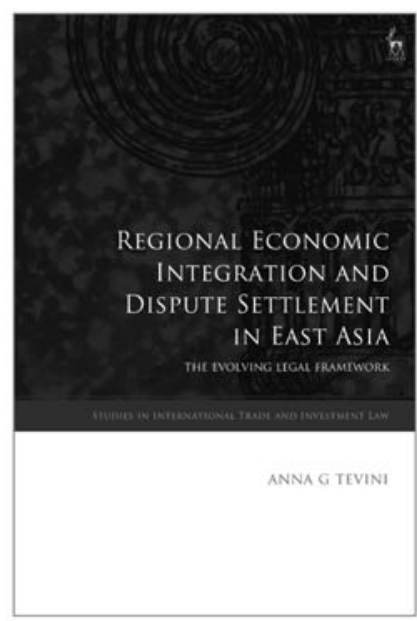

June 2018

US $\$ 136$ 


\section{Oxford University Press NEW TITLES IN INTERNATIONAL LAW}

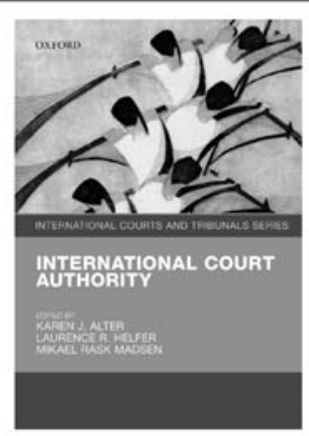

Necessary Evil

How to Fix Finance by Saving

Human Rights

David Kinley

$2018 \mid 288$ pp.

9780190691127 I Hardcover $1 \$ 27.95$

Winner of the ASIL 2018 Certificate of Merit for a preeminent contribution to creative scholarship

Is International Law International?

Anthea Roberts

Foreword by Martti Koskenniemi

2017 | 432 pp.

9780190696412 I Hardcover I \$39.95

The Human Rights-Based Approach to Higher Education

Why Human Rights Norms Should Guide Higher Education Law and Policy Jane Kotzmann

$2018 \mid 288$ pp.

9780190863494 I Hardcover I \$85.00

The United Nations Principles to

Combat Impunity

A Commentary

Edited by Frank Haldemann and

Thomas Unger

Oxford Commentaries on International Law

2018 | 416 pp.

9780198743606 I Hardcover I \$125.00

Internationalized Armed Conflicts in International Law

Kubo Macak

Oxford Monographs in International

Humanitarian \& Criminal Law

2018 | 304 pp.

9780198819868 | Hardcover | $\$ 90.00$
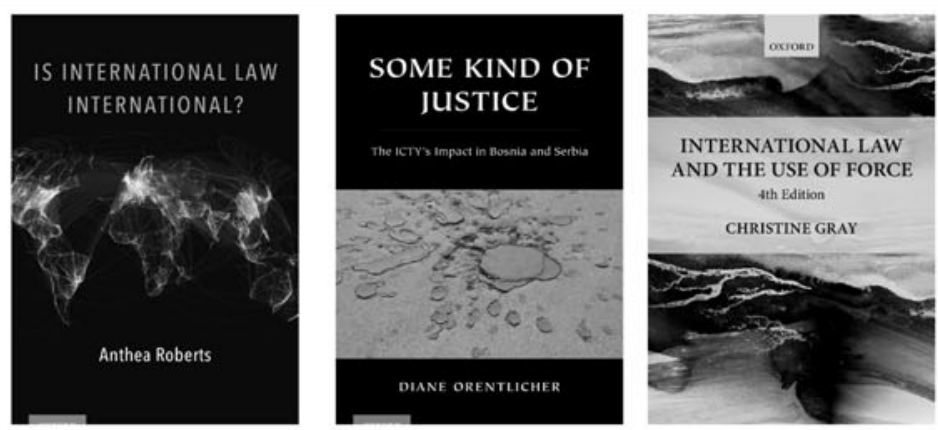

Some Kind of Justice

The ICTY's Impact in Bosnia and Serbia

Diane Orentlicher

2018 | 496 pp.

9780190882273 | Hardcover | \$55.00

International Law and the Use of

Force

Fourth Edition

Christine Gray

2018 | 480 pp.

9780198808428 | Paperback | $\$ 45.00$

9780198808411 | Hardcover | \$125.00

\section{Community Interests Across}

International Law

Edited by Eyal Benvenisti and Georg Nolte

2018 | 544 pp.

9780198825210 | Hardcover | \$125.00

Comparative International Law

Edited by Anthea Roberts, Paul B. Stephan,

Pierre-Hugues Verdier, and Mila Versteeg

2018 | 640 pp.

9780190697570 | Hardcover | \$99.95

International Court Authority

Edited by Karen J. Alter, Laurence R. Helfer and Mikael Rask Madsen

International Courts and Tribunals Series 2018 | 480 pp.

9780198795599 | Paperback | \$39.95

9780198795582 | Hardcover | $\$ 95.00$

An Introduction to Transnational

Criminal Law

Second Edition

Neil Boister

2018 | 512 pp.

9780198796084 | Paperback | \$45.00

9780198795995 | Hardcover | \$125.00
The Handbook of the Law of Visiting

Forces

Second Edition

Edited by Dieter Fleck

$2018 \mid 800$ pp.

9780198808404 | Hardback | \$165.00

The Obligation to Extradite or

Prosecute

Kriangsak Kittichaisaree

2018 | 400 pp.

9780198823292 | Hardcover |\$125.00

The Foundation of Choice of Law

Choice and Equality

Sagi Peari

2018 | 344 pp.

9780190622305 | Hardcover | \$85.00

The Rise of Investor-State Arbitration

Politics, Law, and Unintended

Consequences

Taylor St John

2018 | 304 pp.

9780198789918 | Hardcover | \$80.00

Morality and Responsibility of Rulers European and Chinese Origins of a Rule of Law as Justice for World Order

Edited by Anthony Carty and Janne Nijman

2018 | 550 pp.

9780199670055 | Hardcover | \$99.95

Military Professionalism and

Humanitarian Law

The Struggle to Reduce the Hazards of

War

Yishai Beer

2018 | 240 pp.

9780190881146 | Hardcover | \$85.00 


\section{Oxford University Press NEW TITLES IN INTERNATIONAL LAW}
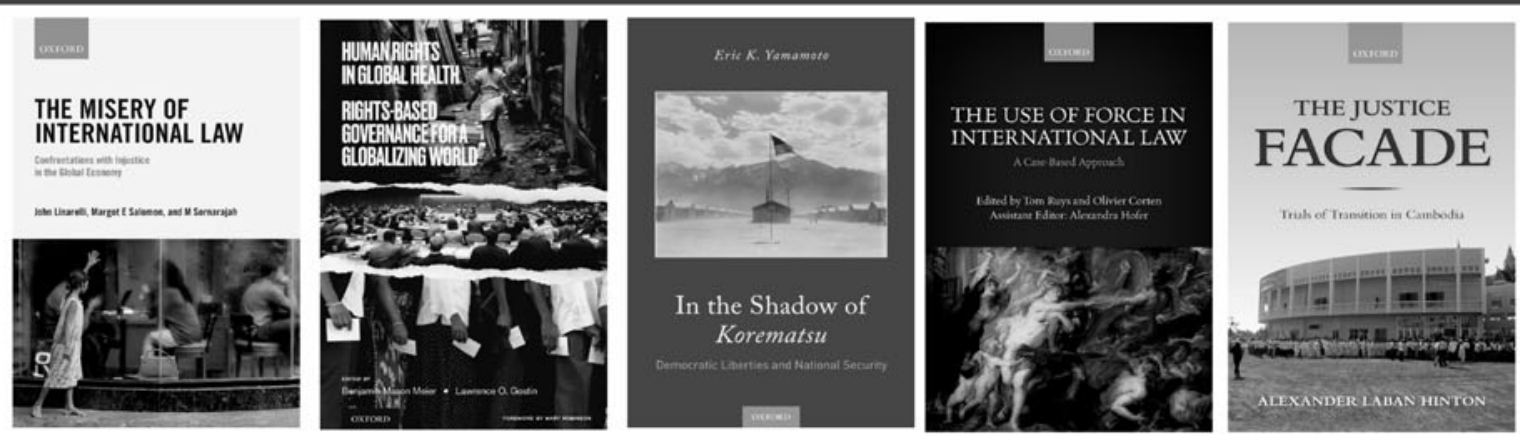

The Misery of International Law Confrontations with Injustice in the Global Economy

John Linarelli, Margot Salomon, and Muthucumaraswamy Sornarajah 20181200 pp.

9780198753957 I Hardcover I \$90.00

The IMLI Treatise on Global Ocean Governance

General Editor David Attard

Volume I: UN and Global Ocean
Governance
Volume Editor David Ong, and
Dino Kritsiotis
2018 | 448 pp.
9780198824152 | Hardcover | \$165.0

Volume II: UN Specialized Agencies and Global Ocean Governance Volume Editor Malgosia Fitzmaurice, and Alexandros Ntovas

2018 | 432 pp.

9780198823964 | Hardcover | \$165.00

Volume III: IMO and Global Ocean

Governance

Volume Editor Rosalie Balkin, and

Donald Greig

2018 | 400 pp.

9780198823957 | Hardcover | \$165.00

Human Rights in Global Health

Rights-Based Governance for a

Globalizing World

Edited by Benjamin Mason Meier and

Lawrence O. Gostin

20181614 pp.

9780190672683 | Paperback | \$54.94

9780190672676 I Hardcover I \$110.00
The Use of Force in International Law In the Shadow of Korematsu A Case-Based Approach Edited by Tom Ruys, Olivier Corten, and Alexandra Hofer $20181960 \mathrm{pp}$.

9780198784364 | Paperback | \$64.99 9780198784357 I Hardcover I \$145.00

The UN Declaration on the Rights of Indigenous Peoples

A Commentary

Edited by Jessie Hohmann and Marc Weller Oxford Commentaries on International Law 2018 | 460 pp.

9780199673223 | Hardcover | \$125.00

The Long Road to Sustainability The Past, Present, and Future of International Environmental Law and Policy Alexander Gillespie

2018 | 280 pp.

The Right to Life in Armed Conflict Ian Park

Oxford Monographs in International Humanitarian and Criminal Law 2018 | 288 pp.

9780198821380 | Hardcover | \$105.00

Organizing Rebellion

Non-State Armed Groups under International Humanitarian Law, Human Rights Law, and International Criminal Law

Tilman Rodenhäuser

Oxford Monographs in International

Humanitarian and Criminal Law

$2018 \mid 400 \mathrm{pp}$.

Democratic Liberties and National

Security

Eric K. Yamamoto

2018 | 264 pp.

9780190878955 | Hardcover | \$39.95

The Justice Facade

Trials of Transition in Cambodia

Alexander Hinton

2018 | 320 pp.

9780198820956 | Paperback | \$29.99

9780198820949 | Hardcover | \$99.95

International Law and the Protection of People at Sea

Irini Papanicolopulu

2018 | 304 pp.

9780198789390 | Hardcover | $\$ 90.00$

A Comparative Guide to the Asian Infrastructure Investment Bank

Natalie Lichtenstein

2018 | 288 pp.

9780198821960 | Hardcover | \$125.00

Race, Criminal Justice, and Migration Control

Enforcing the Boundaries of Belonging

Edited by Mary Bosworth, Alpa Parmar, and Yolanda Vazquez

2018 | 288 pp.

9780198814887 | Hardcover | $\$ 75.00$

Litigating Religions

An Essay on Human Rights, Courts, and Beliefs

Christopher McCrudden

2018 | 192 pp.
9780198819516 | Hardcover | \$90.00

9780198821946 I Hardcover I \$99.95 


\section{Oxford University Press SETTING THE STANDARD IN ONLINE LEGAL RESEARCH}

\section{Oxford International Organizations Primary Materials. Essential Analysis. Expertly Linked.}

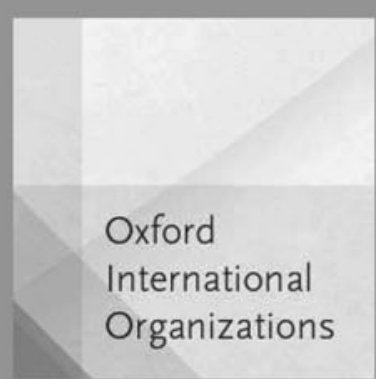

Discover a new online database of materials and analysis relating to the law of international organizations.

Oxford International Organizations (OXIO) collects and analyses primary materials on international organizations (10s), ranging from their constituent instruments, resolutions, agreements with host states, to national and international court decisions and states' declarations and policy statements. The resource includes materials on lesser-known and regional organizations as well as well-known ones such as the UN, WHO, IMF, and World Bank.

\section{oxio.online}

\section{Journals from Oxford University Press}

\section{BRITISH YEARBOOK OF \\ INTERNATIONAL LAW}

Provides up-to-date analysis on important developments in modern international law. It has established a reputation as a showcase for the best in international legal scholarship. academic.oup.com/bybil

\section{EUROPEAN JOURNAL OF INTERNATIONAL LAW}

Offers readers a unique opportunity to stay in touch with the latest developments in international law, with its distinctive combination of theoretical and practical approaches.

academic.oup.com/ejil

\section{CHINESE JOURNAL OF INTERNATIONAL LAW}

A leading forum for articles on international law, with a focus on materials and viewpoints from and/or about China, other parts of Asia, and the broader developing world

academic.oup.com/chinesejil

\section{ICSID REVIEW}

Specialized periodical devoted to foreign investment law and international investment dispute settlement.

It offers articles, case comments, documents, and book reviews. academic.oup.com/icsidreview

\section{LONDON REVIEW OF}

INTERNATIONAL LAW

Reflecting the pace and reach of developments in international law, the Review seeks to capture the ways in which received ideas are being challenged and reshaped by new subject-matters, participants, conceptual apparatuses, and crossdisciplinary connections. academic.oup.com/Iril

I • CON: INTERNATIONAL

JOURNAL OF COMPARATIVE LAW

Dedicated to advancing the study of international and comparative constitutional law in the broadest sense of the terms. academic.oup.com/icon 
https://doi.org/10.1017/ilm.2018.38 Published online by Cambridge University Press 